\title{
Apatite from the Kimberley Kimberlites (South Africa): Petrography and Mineral Chemistry
}

\author{
Ashton Soltys ${ }^{1}$, Andrea Giuliani ${ }^{1,2}$, David Phillips ${ }^{1}$ \\ ${ }^{1}$ KiDs (Kimberlites and Diamonds), School of Earth Sciences, The Univeristy of Melbourne, Parkville, 3010 \\ Victoria, Australia \\ soltysa@student.unimelb.edu.au \\ ${ }^{2}$ ARC Centre of Excellence for Core to Crust Fluid Systems and GEMOC, Department of Earth and Planetary \\ Sciences, Macquarie University, North Ryde, 2019 NSW, Australia
}

\section{Introduction}

Apatite $\left(\mathrm{Ca}_{5}\left(\mathrm{PO}_{4}\right)_{3}(\mathrm{~F}, \mathrm{Cl}, \mathrm{OH})\right)$ is a common accessory phase in a variety of igneous, metamorphic, and sedimentary rocks on Earth, as well as a diverse range of extra-terrestrial bodies (e.g., the Moon, Mars, and meteorites). Apatite is a robust mineral that is commonly used in thermochronology and geochronology studies, for tracing magmatic evolution (e.g., Chakhmouradian et al., 2017), and as a discrimination tool for exploration purposes (e.g., Mao et al., 2016).

Apatite is a near ubiquitous, late-stage, groundmass phase in archetypal kimberlites worldwide (e.g., Mitchell, 1986). In addition, it is a magmatic phase that does not contain xenocrystic components, unlike many other apparently magmatic phases in kimberlites (e.g., spinel, olivine, ilmenite, mica). Despite this, major element data for apatite in kimberlitic apatite is sparse (e.g., Chakhmouradian et al., 2002; Mitchell, 1986), in contrast with the numerous analyses published for other kimberlitic minerals, such as olivine, spinel, and mica (e.g., Mitchell, 1986; Roeder and Schulze, 2008, and references therein). In this contribution, we report the petrography and major-minor element chemistry of apatite from the Kimberley kimberlites (South Africa). The studied samples are derived from the Kimberley Mine, De Beers, Wesselton (units W2 and W3 - Shee, 1985), Wesselton water tunnel sills, and Benfontein. The samples range in texture from "evolved" aphanitic kimberlites (i.e., without olivine macrocrysts Benfontein) to highly macrocrystic kimberlites (i.e., $~ 30$ vol.\% olivine macrocrysts - Wesselton (W3) and Kimberley Mine).

\section{Apatite Petrography}

Apatite from the Kimberley kimberlites occurs in two textural settings: (1) discrete subhedral-euhedral hexagonal prisms, which range from $\sim 1-100 \mu \mathrm{m}$ in size, with most grains $\sim 20-50 \mu \mathrm{m}$ in length and characterised by hopper-like crystal forms; and (2) aggregates of elongate (up to $400 \mu \mathrm{m}$ in length) acicular apatite with radial growth forms that are confined to carbonate-rich or carbonate-serpentine segregations These textural descriptions are consistent with previous petrographic reports of apatite in kimberlites (e.g., Mitchell, 1986; Malarkey et al., 2010), and both textural types commonly occur within the same thin section.

Most apatite grains appear unzoned in back-scattered electron (BSE) images, except for apatite from the Kimberley Mine which have a thin $(<5 \mu \mathrm{m})$ overgrowth of Na-rich apatite $\left(\sim 3.5\right.$ wt. $\% \mathrm{Na}_{2} \mathrm{O}$ based on semi-quantitative SEM-EDS measurement). Acicular apatite in radial aggregates associated with carbonate-rich segregations of the Wesselton water tunnel sills show zonation under cathodoluminescence (CL); however, no compositional variation was detected by EMP analysis, consistent with the lack of change in BSE response, and findings from previous studies of various other rock types (e.g., carbonatites, porphyries, skarns - Mao et al., 2016)

\section{Apatite Composition}

Average compositions of apatite from the Kimberley kimberlites are reported in Table 1. Measured grains can effectively be considered as solid solutions between fluorapatite $(2.2 \pm 0.4 \mathrm{wt} . \% \mathrm{~F})$ and hydroxyapatite $\left(0.70 \pm 0.20 \mathrm{wt} . \% \mathrm{H}_{2} \mathrm{O}\right)$, with a negligible chlorapatite component $(\mathrm{Cl}$ was below the 
detection limits of EMP measurements in most instances). Apatite from serpentine-rich segregations in the De Beers kimberlite have the highest $\mathrm{H}_{2} \mathrm{O}$ contents $(1.0 \pm 0.1 \mathrm{wt} . \%)$. The studied apatite grains contain relatively homogeneous $\mathrm{CaO}\left(55.0 \pm 1.0\right.$ wt.\%) and $\mathrm{P}_{2} \mathrm{O}_{5}(38.9 \pm 0.7 \mathrm{wt} . \%)$ contents. Minor impurities include variable $\mathrm{SiO}_{2}(0.77 \pm 0.48$ wt.\%) and $\mathrm{SrO}(2.1 \pm 1.4$ wt. $\%)$ contents, as well as subordinate concentrations of $\mathrm{Na}_{2} \mathrm{O}(\leq 0.4$ wt.\%), $\mathrm{FeO}(\leq 0.5$ wt.\%), and LREE oxides $(\leq 0.3$ wt.\% $\mathrm{Ce}_{2} \mathrm{O}_{3}$ ) in some samples. These compositions are broadly consistent with the limited published data available (e.g., Mitchell, 1986).

\begin{tabular}{|c|c|c|c|c|c|c|c|c|c|c|c|c|}
\hline & \multicolumn{2}{|c|}{ (1), $n=7$} & \multicolumn{2}{|c|}{ (2), $n=14$} & \multicolumn{2}{|c|}{ (3), $n=13$} & \multicolumn{2}{|c|}{ (4), $n=24$} & \multicolumn{2}{|c|}{ (5), $n=8$} & \multicolumn{2}{|c|}{ (6), $n=19$} \\
\hline & Mean & $1 \sigma$ & Mean & $1 \sigma$ & Mean & $1 \sigma$ & Mean & $1 \sigma$ & Mean & $1 \sigma$ & Mean & $1 \sigma$ \\
\hline $\mathrm{SiO}_{2}$ & 0.70 & 0.18 & 0.30 & 0.17 & 0.60 & 0.12 & 0.47 & 0.10 & 1.51 & 0.40 & 1.36 & 0.15 \\
\hline $\mathrm{TiO}_{2}$ & 0.02 & 0.01 & 0.03 & 0.06 & 0.02 & 0.01 & 0.02 & 0.03 & 0.00 & 0.00 & 0.01 & 0.02 \\
\hline $\mathrm{Fe}_{2} \mathrm{O}_{3}$ & 0.26 & 0.07 & 0.13 & 0.05 & 0.21 & 0.06 & 0.28 & 0.07 & 0.06 & 0.05 & 0.16 & 0.08 \\
\hline MgO & 0.12 & 0.13 & 0.02 & 0.02 & 0.04 & 0.03 & 0.03 & 0.04 & 0.04 & 0.02 & 0.07 & 0.02 \\
\hline $\mathrm{CaO}$ & 53.58 & 0.56 & 55.75 & 0.62 & 56.05 & 0.38 & 53.98 & 0.75 & 55.16 & 0.15 & 55.47 & 0.41 \\
\hline $\mathrm{Na}_{2} \mathrm{O}$ & 0.24 & 0.07 & 0.13 & 0.11 & 0.05 & 0.02 & 0.19 & 0.10 & 0.11 & 0.05 & 0.08 & 0.02 \\
\hline $\mathbf{P}_{2} \mathbf{O}_{5}$ & 38.03 & 0.45 & 39.50 & 0.45 & 39.50 & 0.37 & 38.52 & 0.56 & 38.74 & 0.65 & 38.91 & 0.43 \\
\hline SrO & 3.46 & 0.27 & 1.68 & 0.67 & 1.18 & 0.12 & 3.73 & 0.80 & 1.40 & 0.11 & 0.61 & 0.07 \\
\hline $\mathrm{La}_{2} \mathrm{O}_{3}$ & 0.04 & 0.04 & 0.02 & 0.03 & 0.08 & 0.05 & 0.04 & 0.04 & 0.05 & 0.05 & 0.16 & 0.05 \\
\hline $\mathrm{Ce}_{2} \mathrm{O}_{3}$ & 0.00 & 0.00 & 0.02 & 0.03 & 0.03 & 0.03 & 0.00 & 0.01 & 0.03 & 0.04 & 0.22 & 0.06 \\
\hline $\mathrm{SO}_{3}$ & 0.06 & 0.03 & 0.07 & 0.03 & 0.03 & 0.02 & 0.05 & 0.03 & 0.04 & 0.04 & 0.04 & 0.03 \\
\hline $\mathbf{F}$ & 2.65 & 0.34 & 1.56 & 0.23 & 2.55 & 0.22 & 2.33 & 0.22 & 2.16 & 0.23 & 2.01 & 0.18 \\
\hline Cl & 0.00 & 0.00 & 0.02 & 0.04 & 0.01 & 0.01 & 0.01 & 0.01 & 0.02 & 0.02 & 0.03 & 0.01 \\
\hline $\mathrm{H}_{2} \mathrm{O}(\mathrm{c})$ & 0.45 & 0.16 & 1.00 & 0.11 & 0.54 & 0.10 & 0.61 & 0.10 & 0.72 & 0.11 & 0.78 & 0.08 \\
\hline $\mathrm{O}=\mathrm{F}$ & 1.11 & 0.14 & 0.66 & 0.09 & 1.08 & 0.09 & 0.98 & 0.09 & 0.91 & 0.10 & 0.85 & 0.08 \\
\hline $\mathrm{O}=\mathrm{Cl}$ & 0.00 & 0.00 & 0.00 & 0.01 & 0.00 & 0.00 & 0.00 & 0.00 & 0.00 & 0.00 & 0.01 & 0.00 \\
\hline Total & 98.58 & 0.48 & 99.61 & 0.71 & 99.86 & 0.53 & 99.32 & 0.63 & 99.17 & 0.48 & 99.10 & 0.57 \\
\hline
\end{tabular}

Table 1: Average compositions of apatite from the Kimberley Kimberlites: (1) Kimberley Mine; (2) De Beers; (3) Wesselton (W2); (4) Wesselton (W3); (5) Wesselton water tunnel sills; (6) Benfontein.

Apatite from more "evolved" aphanitic carbonate-rich dykes and sills (i.e., Benfontein and Wesselton Water Tunnel Sills) are generally enriched in $\mathrm{SiO}_{2}$ (and LREE in the case of Benfontein), and generally poorer in $\mathrm{Na}_{2} \mathrm{O}$ and $\mathrm{SrO}$, compared with apatite in macrocrystic kimberlites (i.e., Kimberley Mine and Wesselton) (Fig. 1; Table. 1). In addition, bi-variate major-minor element plots can be used to discriminate between different kimberlite samples and, probably, intrusions (e.g., Fig. 1). Apatite compositions exhibit more variation between intrusions than either spinel or olivine from the Kimberley kimberlites (our unpublished results). This may be attributed to the fact that apatite is a relatively latestage phase in kimberlites (compared with olivine or spinel) and therefore may be more sensitive to the effects of magmatic differentiation.

Although the current apatite grains show variation between intrusions across the Kimberley kimberlites, when compared with other rock types, kimberlitic apatite grains exhibit relatively narrow compositional ranges. For instance, kimberlitic apatite grains contain lower $\mathrm{SrO}$ and $\mathrm{SiO}_{2}$ than those in South African orangeites (e.g., Mitchell, 1995, and references therein), and significantly less $\mathrm{BaO}$ and $\mathrm{TiO}_{2}$ compared to apatite in Western Australian lamproites (Edgar, 1989). In addition, the low $\mathrm{Cl}$ concentrations of kimberlitic apatite overlap those of apatite in carbonatites (Piccoli and Candella, 2002, and references therein); however, kimberlitic apatite does not show the same excess of $\mathrm{F}$ in the anion site, potentially suggesting lower $\mathrm{CO}_{3}{ }^{2-}$ concentrations in kimberlitic apatite. In addition, kimberlitic apatite grains generally contain less $\mathrm{MnO}, \mathrm{Na}_{2} \mathrm{O}$, and $\mathrm{S}$ than carbonatitic apatite. These differences in apatite composition appear to reflect variations in bulk-rock composition between these magma types (i.e., carbonatites contain more $\mathrm{MnO}, \mathrm{Na}_{2} \mathrm{O}, \mathrm{CO}_{2}$ and $\mathrm{S}$ than kimberlites). 


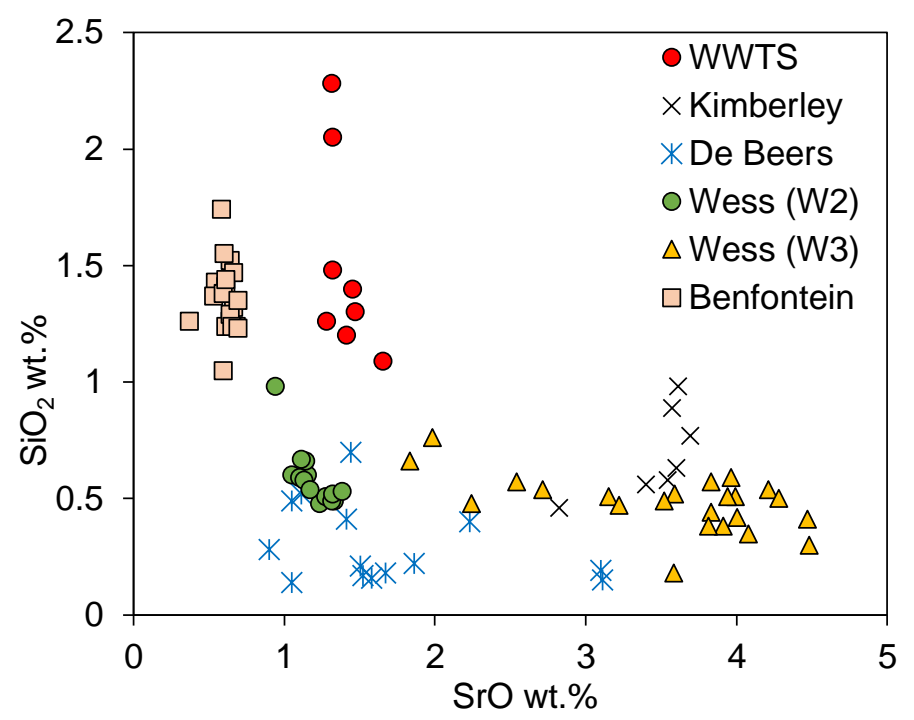

Figure 1: $\mathrm{SiO}_{2}$ vs. SrO varations for apatite grains from the Kimberley Kimberlites.

\section{References}

Chakhmouradian AR, Reguir EP, Mitchell RH (2002). Strontium-apatite: New occurrences, and the extent of Sr-for-Ca substitution in apatite-group minerals. The Canadian Mineralogist, 40(1), 121136.

Chakhmouradian AR, Reguir EP, Zaitsev AN, Couëslan C, Xu C, Kynický J, Mumin AH, Yang P (2017). Apatite in carbonatitic rocks: Compositional variation, zoning, element partitioning and petrogenetic significance. Lithos.

Edgar AD (1989). Barium-and strontium-enriched apatites in lamproites from West Kimberley, Western Australia. American Mineralogist, 74(7-8), 889-895.

Malarkey J, Pearson DG, Kjarsgaard BA, Davidson JP, Nowell GM, Ottley CJ, Stammer J (2010). From source to crust: tracing magmatic evolution in a kimberlite and a melilitite using microsample geochemistry. Earth and Planetary Science Letters, 299(1), 80-90.

Mao M, Rukhlov AS, Rowins SM, Spence J, Coogan LA (2016). Apatite trace element compositions: A robust new tool for mineral exploration. Economic Geology, 111(5), 1187-1222.

Mitchell RH (1986). Kimberlites: mineralogy, geochemistry, and petrology. Plenum Press, New York Mitchell RH (1995). Kimberlite, Orangeites and Related Rocks. Plenum Press, New York. 410pp

Piccoli PM, Candela PA (2002). Apatite in igneous systems. Reviews in Mineralogy and Geochemistry, 48(1), 255-292.

Roeder PL, Schulze DJ (2008). Crystallization of groundmass spinel in kimberlite. Journal of Petrology, 49(8), 1473-1495.

Shee SR, (1985). The Petrogenesis of the Wesselton Mine Kimberlites, Kimberley, Cape Province, R.S.A. (Ph.D) Department of Geochemistry. University of Cape Town, South Africa. 